Ibuprofen is deleterious for the development of first trimester human fetal ovary ex vivo

Leverrier-Penna, S.; Mitchell, R. T.; Becker, E.; Lecante, L.; Ben Maamar, M.; Homer, N.;

Lavoue, V.; Kristensen, D. M.; Dejucq-Rainsford, N.; Jegou, B.; Mazaud-Guittot, S.

Published in:

Human Reproduction

DOI:

10.1093/humrep/dex383

Publication date:

2018

Document version

Publisher's PDF, also known as Version of record

Citation for published version (APA):

Leverrier-Penna, S., Mitchell, R. T., Becker, E., Lecante, L., Ben Maamar, M., Homer, N., Lavoue, V.,

Kristensen, D. M., Dejucq-Rainsford, N., Jegou, B., \& Mazaud-Guittot, S. (2018). Ibuprofen is deleterious for the development of first trimester human fetal ovary ex vivo. Human Reproduction, 33(3), 482-493.

https://doi.org/10.1093/humrep/dex383 


\title{
Ibuprofen is deleterious for the development of first trimester human fetal ovary ex vivo
}

\author{
S. Leverrier-Penna', R.T. Mitchell ${ }^{2}$, E. Becker', L. Lecante', \\ M. Ben Maamar', N. Homer², V. Lavoué ${ }^{3}$, D.M. Kristensen ${ }^{4}$, \\ N. Dejucq-Rainsford', B. Jégou ',5, and S. Mazaud-Guittot ${ }^{\text {I,* }}$
}

\footnotetext{
'Univ Rennes, Inserm, EHESP, Irset (Institut de Recherche en Santé, Environnement et Travail) UMR S I 085, F-35000 Rennes, France ${ }^{2}$ MRC Centre for Reproductive Health, University of Edinburgh, The Queens Medical Research Institute, 47 Little France Crescent, Edinburgh EHI6 4TJ, UK ${ }^{3} \mathrm{CHU}$ Rennes, Service Gynécologie et Obstetrique, F-35000 Rennes, France ${ }^{4}$ Novo Nordisk Center for Protein Research, Faculty of Health and Medical Sciences, University of Copenhagen, Denmark ${ }^{5}$ EHESP_School of Public health, Avenue du Professeur Léon-Bernard, F-35043 Rennes, France

*Correspondence address. Séverine Mazaud-Guittot. Irset—Inserm U1 085, 9 avenue du Pr Léon Bernard, F-35000 Rennes, France. Tel: +33-2-23-23-58-86; E-mail: severine.mazaud@univ-rennes I.fr
}

Submitted on October 17, 20 I7; resubmitted on December 7, 20 I7; accepted on January I, 2018

STUDY QUESTION: Does ibuprofen use during the first trimester of pregnancy interfere with the development of the human fetal ovary? SUMMARY ANSWER: In human fetuses, ibuprofen exposure is deleterious for ovarian germ cells.

WHAT IS KNOWN ALREADY: In utero stages of ovarian development define the future reproductive capacity of a woman. In rodents, analgesics can impair the development of the fetal ovary leading to early onset of fertility failure. Ibuprofen, which is available over-thecounter, has been reported as a frequently consumed medication during pregnancy, especially during the first trimester when the ovarian germ cells undergo crucial steps of proliferation and differentiation.

STUDY DESIGN, SIZE, DURATION: Organotypic cultures of human ovaries obtained from 7 to 12 developmental week (DW) fetuses were exposed to ibuprofen at I-100 $\mu \mathrm{M}$ for 2, 4 or 7 days. For each individual, a control culture (vehicle) was included and compared to its treated counterpart. A total of 185 individual samples were included.

PARTICIPANTS/MATERIALS, SETTING, METHODS: Ovarian explants were analyzed by flow cytometry, immunohistochemistry and quantitative PCR. Endpoints focused on ovarian cell number, cell death, proliferation and germ cell complement. To analyze the possible range of exposure, ibuprofen was measured in the umbilical cord blood from the women exposed or not to ibuprofen prior to termination of pregnancy.

MAIN RESULTS AND THE ROLE OF CHANCE: Human ovarian explants exposed to 10 and $100 \mu M$ ibuprofen showed reduced cell number, less proliferating cells, increased apoptosis and a dramatic loss of germ cell number, regardless of the gestational age of the fetus. Significant effects were observed after 7 days of exposure to $10 \mu \mathrm{M}$ ibuprofen. At this concentration, apoptosis was observed as early as 2 days of treatment, along with a decrease in M2A-positive germ cell number. These deleterious effects of ibuprofen were not fully rescued after 5 days of drug withdrawal.

LARGE SCALE DATA: N/A.

LIMITATIONS, REASONS FOR CAUTION: This study was performed in an experimental setting of human ovaries explants exposed to the drug in culture, which may not fully recapitulate the complexity of in vivo exposure and organ development. Inter-individual variability is also to be taken into account.

WIDER IMPLICATIONS OF THE FINDINGS: Whereas ibuprofen is currently only contra-indicated after 24 weeks of pregnancy, our results points to a deleterious effect of this drug on first trimester fetal ovaries ex vivo. These findings deserve to be considered in light of the

(C) The Author(s) 2018. Published by Oxford University Press on behalf of the European Society of Human Reproduction and Embryology

This is an Open Access article distributed under the terms of the Creative Commons Attribution Non-Commercial License (http://creativecommons.org/licenses/by-nc/4.0/), which permits non-commercial re-use, distribution, and reproduction in any medium, provided the original work is properly cited. For commercial re-use, please contact journals.permissions@oup.com 
present recommendations about ibuprofen consumption pregnancy, and reveal the urgent need for further investigations on the cellular and molecular mechanisms that underlie the effect of ibuprofen on fetal ovary development.

Key words: ovary / ibuprofen / oogonia / apoptosis / necrosis / cell proliferation / TP53

\section{Introduction}

Nonsteroidal anti-inflammatory drugs (NSAIDs) are one of the most commonly used over-the counter (OTC) medications for the treatment of pain, inflammation and fever, with ibuprofen representing a significant share of the market (Kristensen et al., 2016). In 2013, up to $28.3 \%$ of pregnant women reported the use of ibuprofen at some stages during their pregnancy (Van Marter et al., 20I3), ranking ibuprofen as the second most used OTC analgesic after paracetamol (Thorpe et al., 20I3). Although ibuprofen is clearly contra-indicated from 24 weeks of gestation onwards because of well-known risks of malformations, guidelines are more equivocal prior to 24 weeks. Moreover, the consumption of ibuprofen during early pregnancy can also occur due to unawareness of the pregnant state, or through ignoring the composition of the self-medicated drugs that are being used.

During fetal life, the ovarian germ cell population goes through a series of complex processes, initiating with germ cell specification and migration into the gonad, followed by proliferation and entry into meiosis, and culminating in the formation of primordial follicles (Edson et al., 2009). More specifically, during the first trimester of pregnancy, ovarian dynamic developmental events are regulated by the germ cell niche which govern the balance between germ cell proliferation, differentiation and cell death (Kerr et al., 2013). Normal fetal development of the ovary, i.e. the establishment of a dynamic — but finite-reserve of follicles, defines the future reproductive capacity of the woman (McGee and Hsueh, 2000). A poorly stocked initial reserve will result in a shortened reproductive life span, early menopause or infertility (Nelson et al., 2013), events that occur decades later.

Ibuprofen, like all NSAIDs, works by blocking cyclooxygenases (COX), key enzymes involved in the first rate-limiting step in the conversion of arachidonic acid into prostaglandins (PG) (Rainsford, 2009). In the human fetal ovary, the constitutively expressed COXI is primarily found in somatic cells, whereas the inducible COX2 is restricted to the periphery of the ovary where pluripotent germ cells are located, inferring COX2 involvement in ovarian development (Bayne et al., 2009). Despite evidence implicating PGs and COXs as critical factors in adult female reproductive function (Duffy, 20I5; Sugimoto et al., 2015), little is known about their precise function in human ovarian organogenesis. However, prostaglandin E2 (PGE2) signaling was related to enhanced expression of germ cell survival genes in human fetal ovaries (Bayne et al., 2009), and analgesics were found to induce cell death in human ovarian cancer cell lines (Andrews et al., 2008; Zerbini et al., 201 I; Duncan et al., 2012; Lima et al., 2015). Therefore, we hypothesized that exposure of the developing ovary to COX inhibitors may have toxic effects on germ and/or somatic cells.

The scientific community is raising increasing concerns about the impact of environmental and pharmaceutical chemicals on the fetus development. This includes pain medications which induce endocrine disruption of the human fetal testis (Mazaud-Guittot et al., 2013;
Kristensen et al., 2016; Ben Maamar et al., 2017) and result in infertility and premature ovarian insufficiency in mice and rats (Dean et al., 2016; Holm et al., 20 I6; Johansson et al., 2016). To date, there is insufficient evidence concerning short-term effects of ibuprofen on fetal organogenesis, and the prediction of long-term adverse effects of this common medicine in adults. Therefore, the objective of the present study was to assess the possible effects of ibuprofen on the human fetal ovary, with a focus on cell viability, window of sensitivity, target specificity and reversibility, during the key stages of female fetal germ cell development along the first trimester. To this end, we used an original ex vivo model of human fetal ovary organotypic culture, which we exposed to a range of ibuprofen concentrations for various durations. Our results show that in the developing human ovary, germ cells are particularly sensitive to ibuprofen damage.

\section{Materials and Methods}

\section{Ethics statement}

First trimester human fetuses (7-12 developmental weeks (DW), $n=185$ ) were obtained from legally induced terminations of pregnancy performed in Rennes University Hospital from October 2013 to June 2017. No termination of pregnancy was due to fetal abnormality. Tissues were collected following women's written consent, in accordance with the legal procedure agreed by the National agency for biomedical research (authorization \#PFS09-0I I; Agence de la Biomédecine) and the approval of the Local ethics committee of Rennes Hospital (advice \# I I-48) approved the whole procedure.

\section{Human fetal ovary collection}

The termination of pregnancy was induced using a standard combined Mifegyne ${ }^{\circledR}$ (mifepristone) and Cytotec ${ }^{\circledR}$ (misoprostol) protocol, followed by aspiration. A subset of women received either 400 or $800 \mathrm{mg}$ of ibuprofen for preventive analgesia or none. The potential effect of ibuprofen intake prior termination was taken into account when analyzing the data. Gestational age was determined by ultrasound, and further confirmed by measurement of foot length. Blood was collected from umbilical cord from fetuses older than $8 \mathrm{DW}$, samples were centrifuged and serum was stored at $-80^{\circ} \mathrm{C}$. The ovaries were recovered from the aspiration products using a binocular microscope (Olympus SZX7, Lille, France). They were immediately placed in ice-cold phosphate-buffered saline (PBS).

\section{Ex vivo culture}

The recovered ovaries were cut into $\sim 1 \mathrm{~mm}^{3}$ pieces and explants were cultured in cell culture inserts $(0.4 \mu \mathrm{M}$ pores) placed in 24 -well companion plates (Becton-Dickinson, Le Pont de Claix, France). Ovaries from fetuses younger than I0 DW were cultured in two separate wells, one ovary being exposed to vehicle and the other one to ibuprofen. Ovaries from fetuses older than $10 \mathrm{DW}$ were either cultured in one well (for hormone measurements) or four wells for multiple culture (i.e. one control and three ibuprofen concentrations) conditions. Ovaries were halved lengthways and each half was divided into 2-3 ovary pieces. Each well was filled with 
$400 \mu \mathrm{l}$ of phenol red-free Medium 199 (Invitrogen Life Technologies, Cergy Pontoise, France) supplemented with $50 \mu \mathrm{g} / \mathrm{ml}$ gentamycin, $2.5 \mu \mathrm{g} / \mathrm{ml}$ fungizone (Sigma Aldrich Chemicals, Saint-Quentin Fallavier, France) and insulin $(\mathrm{I} \mathrm{g} / \mathrm{l})$, transferrin $(0.55 \mathrm{~g} / \mathrm{l})$ and sodium selenite $(0.67 \mathrm{mg} / \mathrm{l})$ (Sigma Aldrich Chemicals). Cultures were incubated at $37^{\circ} \mathrm{C}$ for up to 7 days under a humidified atmosphere of $95 \%$ air and $5 \% \mathrm{CO}_{2}$. The medium was replaced with fresh media after the first $24 \mathrm{~h}$ and then every $48 \mathrm{~h}$, immediately snapfrozen on dry ice and stored at $-80^{\circ} \mathrm{C}$. Explants were immediately exposed to treatments by adding to the medium either vehicle at a final concentration of $0.1 \% \mathrm{v} / \mathrm{v}$ (dimethyl sulfoxide; DMSO) or ibuprofen (Sigma Aldrich Chemicals). Since therapeutic concentrations of ibuprofen in the plasma range from 10 to $200 \mu \mathrm{M}$ (Kallstrom et al., 1988; Karttunen et al., 1990), concentrations of analgesics used in the current study were $10 \mu \mathrm{M}$ to test common treatment effect, and $\mathrm{I}-100 \mu \mathrm{M}$ to assess potential dose-response effects.

\section{Single cell dissociation and flow cytometry}

Explants were submitted to a sequential enzymatic digestion procedure adapted from Le Bouffant et al. (2010) in order to obtain single cell suspensions. Briefly, ovarian pieces were first digested in 0.25\% Trypsin- $0.02 \%$ EDTA ( $w / v)$ (\#T4049, Sigma-Aldrich) for $5 \mathrm{~min}$ at $37^{\circ} \mathrm{C}$. Trypsin digestion was stopped by adding $10 \%$ fetal bovine serum in MI 99 media and samples were centrifuged at $350 \mathrm{~g}$ for $5 \mathrm{~min}$. The samples were then further digested with $2 \mathrm{mg} / \mathrm{ml}$ collagenase (\#COI30, Sigma-Aldrich) and $0.05 \mathrm{mg} /$ $\mathrm{ml}$ DNase (\#DN25, Sigma-Aldrich) in MI99 media for $5 \mathrm{~min}$ at $37^{\circ} \mathrm{C}$. Dispersed cells were centrifuged and resuspended in PBS. Before proceeding to labeling, cell counting was performed on a Malassez Hemocytometer (Trypan blue exclusion of live cells was included). Apoptotic cells were labeled with FITC Annexin-V (BD pharmingen \#5564 I9) following the manufacturer's recommendations, coupled to necrotic nucleus staining with $3 \mu \mathrm{g} / \mathrm{ml}$ 7-Aminoactinomycin D (7-AAD; FluoProbes, Interchim \# I32303) in $100 \mu$ binding buffer. In Annexin- $V$ versus 7-AAD contour plots with quadrant gates, dead cells included apoptosis (early: AnnV+7AAD- and late: AnnV+7AAD+) plus necrosis (AnnV-7AAD+) (Suppl. Fig. SIB). To identify germ cells, a plasma membrane M2A labeling was performed using anti-D240 mouse monoclonal antibody (abcam \# 77854, diluted I:200) in the presence of $10 \%$ FCS and incubated $30 \mathrm{~min}$ at room temperature (RT). Detection was allowed by a R-Phycoerythrin coupled anti-Mouse $\lg \mathrm{G}(\mathrm{H}+$ L) (Jackson ImmunoResearch \# 7/5-I16-I50). To evaluate cell death and germ cell dynamics, a minimum of twenty thousand cells were acquired and analyzed by flow cytometry using a FACSCalibur (BD Biosciences) equipped with CellQuest software.

\section{Immunohistochemistry and stereology}

Immunohistochemistry was performed on 4\% paraformaldehyde-PBS and Bouin solution-fixed, paraffin-embedded ovaries. Each fifth $5 \mu$ m-thick section was used for immunohistochemistry with cell-specific labeling. After unwaxing and rehydration, sections were blocked for $20 \mathrm{~min}$ at RT with $10 \%$ bovine serum albumin (BSA) in PBS before overnight incubation at $4^{\circ} \mathrm{C}$ with the primary antibody diluted in Dako antibody diluent (Dako Cytomation, Trappes, France). Apoptotic cells were stained with a rabbit anti-cleaved caspase-3 antibody (I:150; Cell Signaling Tech. \#966I, Ozyme, Saint Quentin en Yvelines, France), proliferating cells with a mouse anti-Ki67 antibody (1:100; Dako \#M7240) and germ cells with a mouse anti-M2A antibody ( $1: 100$, clone D2-40; Abcam \#ab77854) or a rabbit anti-LIN28 ( I:300, Abcam \#ab46020). An antigen retrieval step at $80^{\circ} \mathrm{C}$ for $40 \mathrm{~min}$ with $10 \mathrm{mM}$ Tris, I mM EDTA buffer, $\mathrm{pH} 9$ for cleaved caspase-3 or $10 \mathrm{mM}$ citrate buffer, $\mathrm{pH} 6$ for Ki67, M2A and LIN28 was necessary. The secondary antibodies were biotinylated goat anti-rabbit or rabbit anti-mouse antibodies (I:500; E0342 and E0464, respectively, Dako). Sections were developed with streptavidin-horseradish peroxidase
(Vectastain ABC kit, Vector Laboratories, Burlingame, CA, USA) and 3,3'-diaminobenzidine tetrahydrochloride (Sigma Aldrich Chemicals) and counterstained with hematoxylin. Stained sections were examined and photographed under the light microscope (Olympus BX5I). Pictures of sections were captured with a scanner NanoZoomer 2.0 RS (Hamamatsu, Tokyo, Japan) at 40x magnification. The surfaces of 5-10 sections covering the whole explant were calculated with NDPview software (Hamamatsu, Tokyo, Japan). ImageJ software (US National Institutes of Health, Bethesda, MD, USA) was used to perform the cell counting based on stereological principles. Cells were counted in at least five sections and apoptotic cells counts reported as number per unit surface area of the section, while proliferating cells are reported as the percentage of Ki67-positive cells in a population of KI67-negative cells.

\section{Prostaglandin measurement}

Prostaglandin E2 (PGE2) levels were measured in culture media of ovarian explants after I day of exposure by an ELISA method (intra-assay CV 3.7-30.4\% and inter-assay CV 6.4-35\%; PG E2 EIA Kit-Monoclonal Cayman Chemical Company, Ann Arbor, MI, USA). Each sample was assayed in duplicate.

\section{Ibuprofen assay}

Ibuprofen was extracted from human plasma by solid phase extraction using $10 \mathrm{mg}$ HLB Oasis cartridges (Waters, UK). Briefly, $50 \mu \mathrm{l}$ plasma was enriched with Ing deuterium-labeled acetaminophen (APAP-d4; Santa Cruz Biotechnology Inc.) as internal standard. Cartridges were conditioned with methanol and water, the sample loaded and washed with water - 5\% methanol and then eluted with I $\mathrm{ml}$ methanol. The eluate was reduced to dryness under nitrogen at $40^{\circ} \mathrm{C}$ and reconstituted in mobile phase $(100 \mu \mathrm{l}$ water/acetonitrile $(70: 30, \mathrm{v} / \mathrm{v}))$. Chromatographic separation was achieved by injecting $20 \mu \mathrm{l}$ sample onto an Acquity UPLC system with an ACE Excel CI8-AR column $(150 \times 2.1 \mathrm{~mm} ; 2 \mu \mathrm{m})$ protected by a Kinetex KrudKatcher (Phenomenex) and operated at $30^{\circ} \mathrm{C}$. Following separation, ibuprofen was detected on a QTrap 5500 triple quadrupole mass spectrometer (Seiex, Warrington, UK) operated in positive ion electrospray mode $\left(5.5 \mathrm{kV}, 550^{\circ} \mathrm{C}\right.$, ion source gas $\left.60 / 40\right)$. Transitions monitored were $\mathrm{m} / \mathrm{z} 207.1 \rightarrow 161.1$ and $\mathrm{m} / \mathrm{z}$ 156.I $\rightarrow$ II4.I for ibuprofen and APAP-d4, respectively. The mobile phase consisted of $0.1 \%$ formic acid (Sigma Aldrich) in water and $0.1 \%$ formic acid in acetonitrile (B) at a flow rate of $0.5 \mathrm{ml} / \mathrm{min}$. Gradient elution was achieved with a total run time of $9 \mathrm{~min}$ from $30 \%$ to $100 \%$ B. Ibuprofen eluted at $5.70 \mathrm{~min}$ and the internal standard, APAP-d4 eluted at $1.1 \mathrm{~min}$.

\section{Quantitative PCR}

RNAs were extracted from ovarian explants using All Prep RNA/DNA/ protein extraction kit (Qiagen) according to manufacturer's instructions. Total RNAs (250 ng) were reverse transcribed with iScript cDNA synthesis kit (Biorad) and quantitative PCR was performed using the iTaq@ universal SYBR green supermix (Biorad) according to manufacturer's instructions in a Cfx384 OneTouch Real-Time PCR system (Biorad). The following amplification program was used: an initial denaturation of 3 min at $95^{\circ} \mathrm{C}, 40$ cycles of $10 \mathrm{~s}$ denaturation at $95^{\circ} \mathrm{C}$ and $30 \mathrm{~s}$ at $62^{\circ} \mathrm{C}$ for annealing and extension. Dissociation curves were produced using a thermal melting profile performed after the last PCR cycle. To avoid amplification of contaminating genomic DNA, primer pairs were selected on either side of an intron. RPLPO and RPS20 mRNA were used as internal controls for normalization (Table I). Results were calculated by the $\Delta \Delta C T$ method as $n$-fold differences in target gene expression, relative to the reference gene and calibrator sample which is constituted of an equal mixture of all the samples tested specifically in each tested organ. 
Table I Primers used for quantitative PCR.

\begin{tabular}{|c|c|c|c|c|}
\hline Gene & Forward (5'-3') & Reverse (5'-3') & Size (bp) & Reference \\
\hline RPLPO & TCTACAACCCTGAAGTGCTTGAT & CAATCTGCAGACAGACACTGG & 96 & Svingen et al. (20|4) \\
\hline RPS20 & AACAAGCCGCAACGTAAAATC & ACGATCCCACGTCTTAGAACC & 166 & Svingen et al. (20|4) \\
\hline CCNBI & TCGAGCAACATACTTTGGCCA & GCAAAAAGCTCCTGCTGCAA & 101 & Wang et al. (20I3) \\
\hline CCNDI & CCGTCCATGCGGAAGATC & GAAGACCTCCTCCTCGCACT & 75 & Yang et al. (20|6) \\
\hline CDKNIA & TCСTTTCCСTTCAGTACССТCTC & ССTTCTTCTTGTGTGTCCCTTCC & 107 & Chang et al. (2013) \\
\hline CHEKI & GGTGCCTATGGAGAAGTTCAA & TCTACGGCACGCTTCATATC & 89 & Selvarajah et al. (20I5) \\
\hline MKI67 & CGAGACGCCTGGTTACTATCAA & GGATACGGATGTCACATTCAATACC & 108 & Kripp et al. (2016) \\
\hline TP53 & CСАТССТСАССАТСАТСАСАСТG & CACAAACACGCACCTCAAAGC & 78 & Chang et al. (2013) \\
\hline
\end{tabular}

\section{Statistical analysis}

For each multivariate analysis (cell death, cell counts), the statistical framework included (i) a global analysis of the effect of exposure to ibuprofen with a non-parametric Kruskal-Wallis sum rank test; (ii) every time a global significant effect was predicted, post-hoc non-parametric tests between control and ibuprofen-treated samples at different dose (from I to $100 \mu \mathrm{M}$ ) or age (from 7 to $12 \mathrm{DW}$ ) were performed (Wilcoxon or MannWhitney tests) and corrected for multiple testing with Bonferroni correction. Statistically significant post-hoc tests are indicated by $\left(^{*}\right)$ if the $P$-value corrected for multiple testing is below 0.05 , $(* *)$ below 0.01 and $(* * *)$ below $0.00 \mathrm{I}$. The free software environment for statistical computing and graphics $\mathrm{R}$ was used to perform the calculations.

\section{Results}

\section{Ibuprofen crosses the placental barrier}

To get insights into the range of concentrations of ibuprofen the fetus can be exposed to, ibuprofen concentration in the umbilical cord of 13 fetuses between 8 and 12 DW were measured (Table II). Ibuprofen concentrations were on average \pm SEM 7.I $\pm 5.02 \mu \mathrm{M}(0.37-14.5 \mu \mathrm{M})$ when pregnant women had ingested $800 \mathrm{mg}$ of ibuprofen $2-5 \mathrm{~h}$ prior to termination of pregnancy. Following ingestion of a single dose of $400 \mathrm{mg}$, ibuprofen concentration was on average \pm SEM $2.09 \pm$ I. $25 \mu \mathrm{M}(0.83-6.95 \mu \mathrm{M})$ in the umbilical serum. Ibuprofen was nondetectable when the women had not used the analgesic ( $n=5$ samples). Consequently, concentrations covering the range of those found in the umbilical blood were chosen for subsequent ex vivo experiments.

\section{Ibuprofen suppresses ovarian prostaglandin E2 production}

One day of exposure to ibuprofen at $10 \mu \mathrm{M}$ significantly decreased by $66.3 \%$ prostaglandin E2 (PGE2) production by explants aged 7-12 DW. The average level $( \pm$ SEM) of PGE2 in control samples was $353 \pm$ $73.9 \mathrm{pg} / \mathrm{ml}(n=2 \mathrm{I})$, while levels were reduced to $119 \pm 10.6 \mathrm{pg} / \mathrm{ml}$ $(n=16)$ in ibuprofen samples $(P=0.0062)$. No age-window of sensitivity for effect on PGE2 production was observed.

\section{Ibuprofen impairs ovarian cell growth}

Fetal ovarian explants (7-12 DW) were exposed for a week to a range of ibuprofen concentrations (from I to $100 \mu \mathrm{M}$ ) and the overall cell
Table II Concentration of ibuprofen in serum from first trimester umbilical cord blood.

\begin{tabular}{|c|c|c|c|}
\hline $\begin{array}{l}\text { Ibuprofen } \\
\text { dose }\end{array}$ & $n$ & $\begin{array}{l}\text { Serum } \\
\text { concentration }(\mu M)\end{array}$ & $\begin{array}{l}\text { Time between drug } \\
\text { consumption and serum } \\
\text { blood collection (h) }\end{array}$ \\
\hline $0 \mathrm{mg}$ & 5 & 0 & \\
\hline \multirow[t]{3}{*}{$400 \mathrm{mg}$} & 5 & 0.83 & 2 \\
\hline & & $2.13 ; 3.36 ; 6.95$ & 3 \\
\hline & & 1.08 & 6 \\
\hline \multirow[t]{2}{*}{$800 \mathrm{mg}$} & 3 & 0.37 & 2 \\
\hline & & $6.36 ;|4.5|$ & 5 \\
\hline
\end{tabular}

number was assessed (Fig. IA). In uncultivated ovaries, the total number of cells per ovary increased exponentially from $2.6 \times 10^{5}$ at $7 \mathrm{DW}$ to $1.3 \times 10^{6}$ at $12 \mathrm{DW}$ (Suppl. Fig. SIA). This number further increased during the 7 days of culture in control conditions (Suppl. Fig. SIA). By contrast, when the organs were exposed to ibuprofen at the concentration of $10 \mu \mathrm{M}$ for 7 days, the total ovarian cell count was significantly reduced (of $-50 \%$ on average) compared to the unexposed controls, regardless of the developmental age of the explant (Fig. IA). Although not significant for every age group, a reduction of the cell number was also observed with a $1 \mu \mathrm{M}$ ( $-20 \%$ on average) and a $100 \mu \mathrm{M}$ dose ( $-20 \%$ on average).

To determine whether ibuprofen-induced ovarian cell depletion could result from a decrease in cell proliferation, we scored the percentage of KI67-positive cells, including both somatic and germ cells, in histological sections after 7 days of culture (Fig. IB and C). Before 8 DW, ibuprofen at all tested concentrations induced a massive decrease in the percentage of KI67-positive cell density. In 8-12 DW explants, cell proliferation also exhibited a statistically significant decline of KI67-positive cell density at I and $10 \mu \mathrm{M}$ ibuprofen, but not at $100 \mu \mathrm{M}$ (Fig. IC).

\section{Ibuprofen induces cell death in the human fetal ovary}

To determine whether the ibuprofen-induced reduction in the number of total ovarian cells could result from a loss of cell viability, cell death 


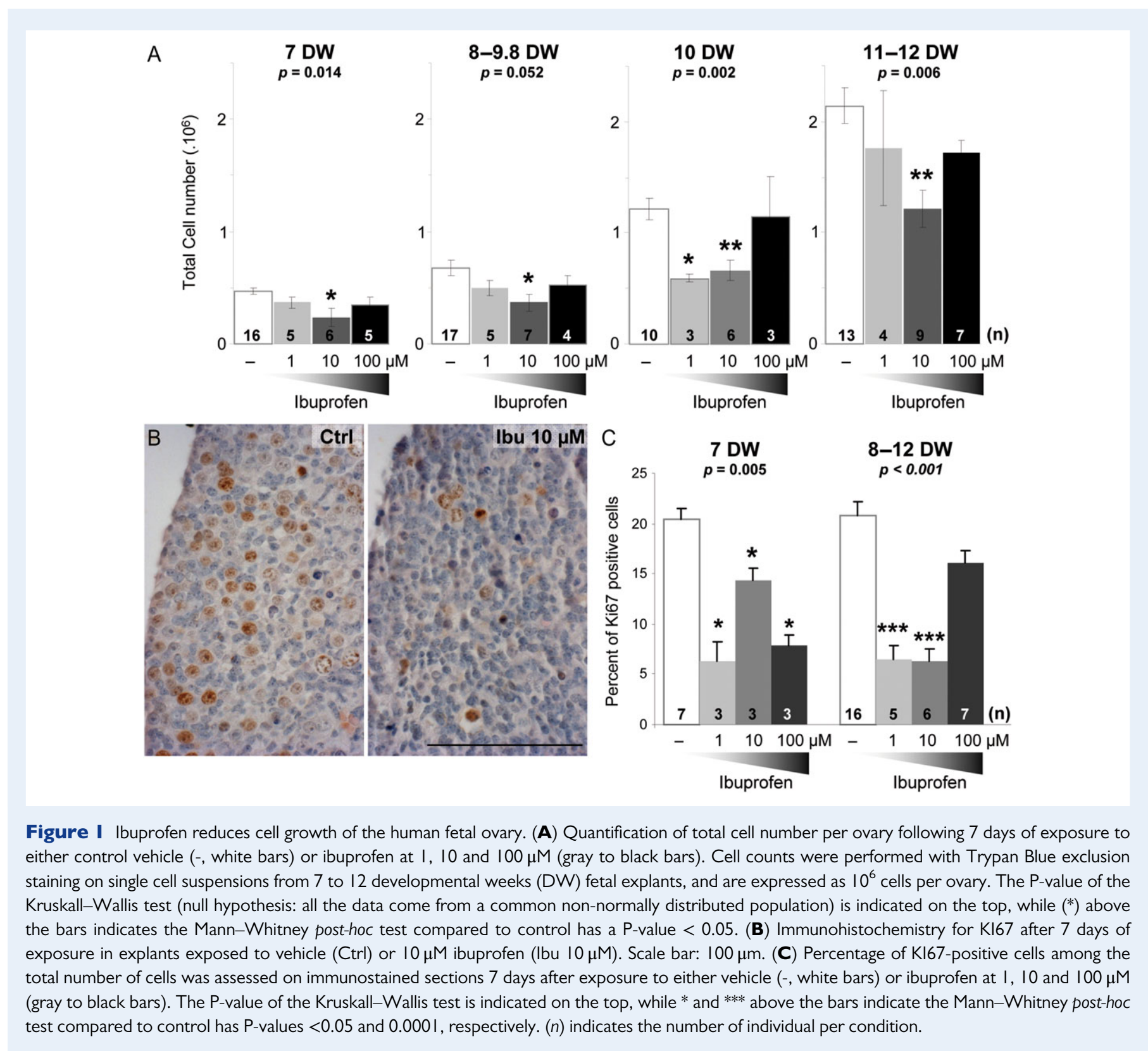

was quantified using a flow cytometry-based Annexin- $V$ labeling coupled with 7-AAD nuclear staining (Suppl. Fig. SIB). Briefly, in Annexin- $V$ versus 7-AAD contour plots with quadrant gates, dead cells include apoptotic cells displaying annexin $V$ in the outer membrane (early: AnnV+7AAD- and late: AnnV+7AAD+) and necrotic cells in which the 7AAD dye could enter the nucleus (AnnV-7AAD+). To eliminate a potential cytotoxic impact of the organotypic culture itself, we assessed cell death before and during the 7 days of culture in control conditions (Suppl. Fig. SIC). Overall, the majority (94-96\%) of the cells appeared to be viable, total cell death only reaching a maximum of $6 \%$. This cell death rate remained stable from Day 0 to Day 7 regardless of the age of the explant.

Following ibuprofen exposure, the percentage of global cell death, including both apoptotic and necrotic death, was consistently higher compared to vehicle-exposed explants for both $7 \mathrm{DW}$ fetuses $(P=$ $0.0028)$ and 8-12 DW fetuses $(P<0.00 \mathrm{I})$ (Fig. 2A). Whilst I $\mu \mathrm{M}$ ibuprofen induced a weak cytotoxic effect, statistically significant only in the 8-12 DW group $(P=0.098,+42 \%$ at $7 \mathrm{DW}$, and $P=0.028$, $+45 \%$ at 8-12 DW), $10 \mu \mathrm{M}$ ibuprofen concentration induced a marked accumulation of dead cells $(P=0.007,+85 \%$ at $7 \mathrm{DW}$, and $P<0.001,+170 \%$ at $8-12 \mathrm{DW}$ ) (Fig. 2A). Notably, the cytotoxic effect of $10 \mu \mathrm{M}$ ibuprofen was intensified in the oldest explant group $(10.47 \pm 2.11$ versus 16.14 \pm 1.88 ; Means \pm SEM of 7 versus $8-12$ DW). When uncoupling apoptosis from necrosis, only the former cell death mechanism significantly increased in both exposed age groups (Fig. 2A).

To further investigate the effects on cell death, a histological analysis on ovarian explant sections was carried out using cleaved caspase- 3 staining as a hallmark of apoptosis (Fig. 2B and C). Overall, exposure to ibuprofen for 7 days resulted in an increase in the density of cleaved caspase-3-positive cells for both 7 and 8-12 DW groups; however this only reached statistical significance in $8-12$ DW fetuses $(P<0.00 \mathrm{I})$ 


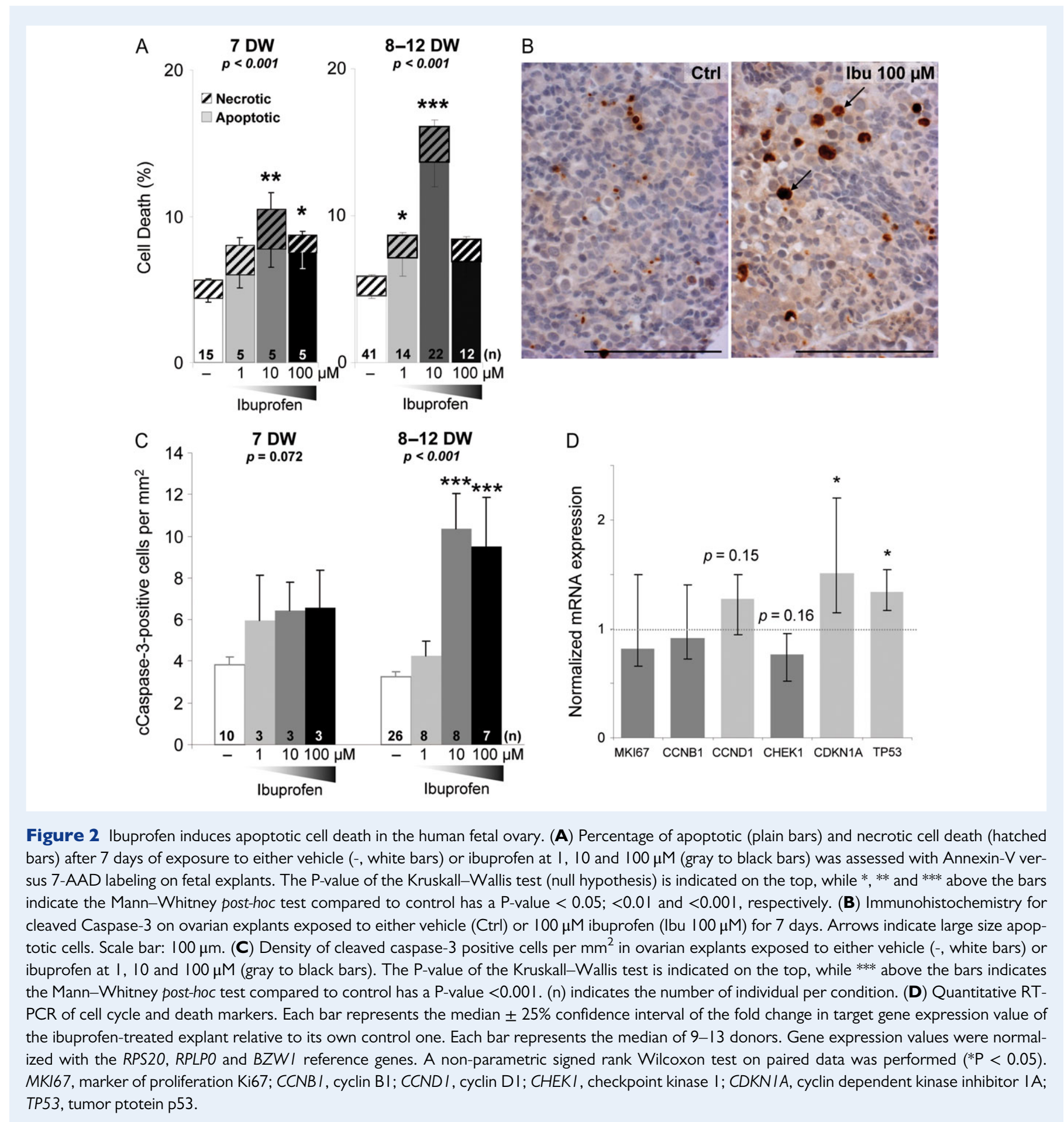

compared to $7 \mathrm{DW}$ fetuses $(P=0.072)$ (Fig. $2 \mathrm{C})$. Both the 10 and $100 \mu \mathrm{M}$ concentrations of ibuprofen induced a dramatic accumulation of apoptotic cells $(P<0.001,+208 \%$, and $+182 \%$, respectively $)$ in 8-12 DW fetuses, whereas the I $\mu \mathrm{M}$ dose-response did not pass the significance threshold. It is noteworthy that the quantitative analysis could not be performed in several 10 and $100 \mu \mathrm{M}$ ibuprofen-exposed tissue sections ( 7 and 2 individuals, respectively) due to a massive degradation and loss of integrity of the tissue itself. These data indicate that ibuprofen is cytotoxic, resulting in apoptosis in 7-12 DW fetal ovaries, with exacerbated effect when gestational age of the fetus increases. Quantitative PCR analysis of several cell proliferation (marker of proliferation Ki67 MKI67), cycle (cyclin BI, CCNBI; Cyclin DI, CCND I; cyclin dependent kinase inhibitor I A, CDKN/A; checkpoint kinase I, CHEKI) and death markers (tumor protein p53, TP53) showed a significant increase in the expression of TP53 and CDKNIA (Fig. 2D). 

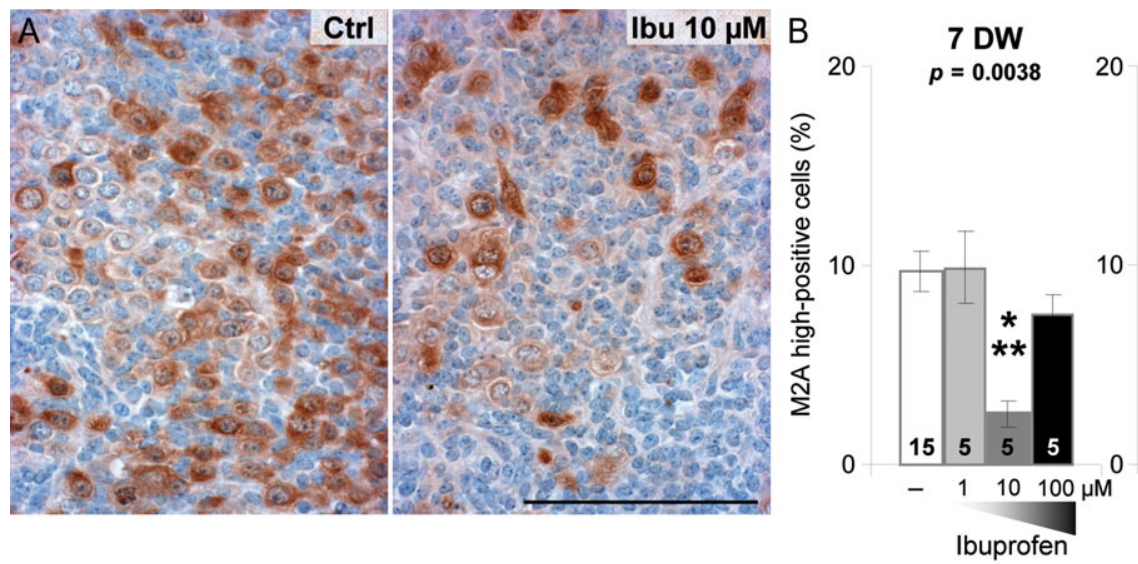

\section{8-12 DW \\ $p<0.001$}

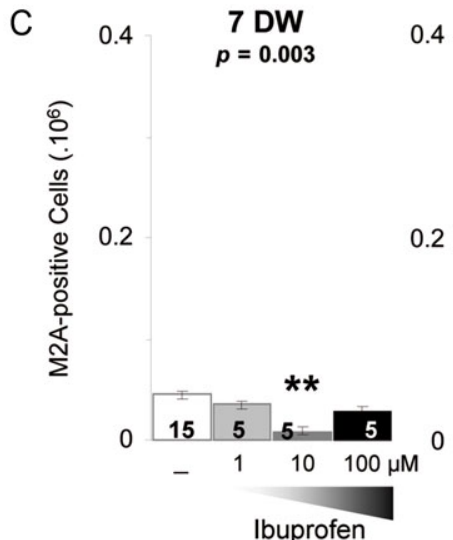

.4

8-9.8 DW

$p=0.01$

0.4

10 DW

$p=0.064$

0.4

$11-12 \mathrm{DW}$
$p=0.0014$

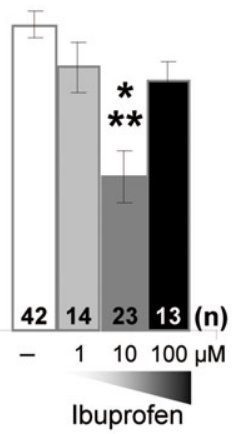

Ibuprofen

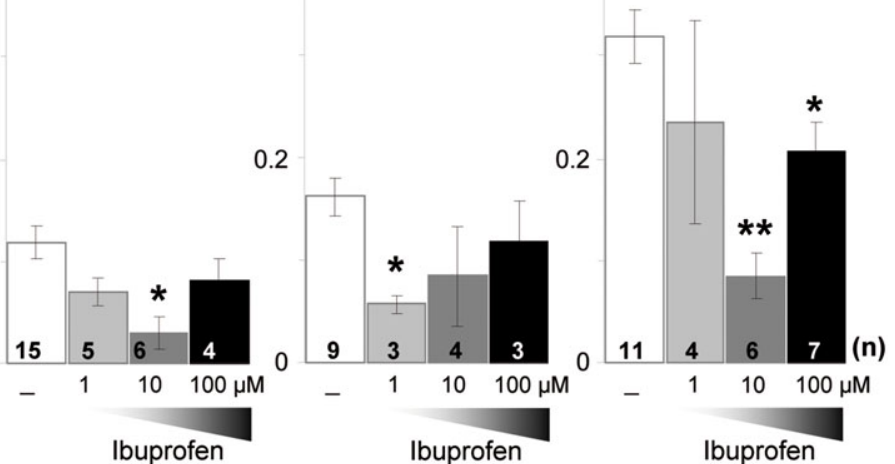

Figure 3 Ibuprofen targets fetal ovarian germ cells. (A) Immunohistochemistry for LIN28 on ovarian explants exposed to either vehicle (control, Ctrl) or $10 \mu \mathrm{M}$ ibuprofen (Ibu 10 $\mu \mathrm{M}$ ) for 7 days. Scale bar: $100 \mu \mathrm{m}$. (B) Percentage of M2A-positive germ cells was assessed by flow cytometry 7 days after exposure to either vehicle (-, white bar) or ibuprofen at I, 10 and $100 \mu \mathrm{M}$ (gray to black bars). The P-value of the Kruskall-Wallis test is indicated on the top, while *** above the bars of the histogram indicates the Mann-Whitney post-hoc test compared to control has a $P$-value $<0.00 I$. (C) Quantification of total M2A-germ cells number per ovary performed on single cell suspensions resulting from fetal ovaries treated as above is expressed as $10^{6}$ germ cells per ovary. The P-value of the Kruskall-Wallis test is indicated on the top, while * and ** above the bars of the histogram indicate the Mann-Whitney posthoc test compared to control has a $\mathrm{P}$-value $<0.05$ and $<0.0$ I, respectively. $(n)$ indicates the number of individual per condition.

\section{Ovarian fetal germ cells are highly sensitive to ibuprofen}

The large size of the cleaved caspase- 3 positive cells revealed by our histological study (Fig. 2B) suggested that the apoptotic cells in ibuprofenexposed explants were likely to be germ cells. To verify our hypothesis, we used an antibody targeting LIN28, a marker of fetal germ cells (Childs et al., 20I2), which revealed a decrease of the density of LIN28-positive cells (Fig. 3A and Suppl. Fig. S2A-B). Another marker of fetal germ cells, M2A (lin et al., 2010) enabled the identification of two populations of germ cells (Suppl. Fig. S2C), as reflected by two distinct peaks in flow cytometry. (Suppl. Fig. S2D). In accordance with the unchanged viability profile observed along the 7 days of culture in control medium (Suppl. Fig. SIC), the percentage of M2A high-positive cells was not affected during the week of ex vivo culture of 7-12 DW explants (Suppl. Fig. S2E). By contrast, the proportion of M2A-germ cells increased steadily between the isolation of the organ (Day 0 ) and the end of the 7 days of culture.

As measured by flow cytometry, the population expressing high levels of $M 2 A$ ( 10 to $>15 \%$ of the total ovarian cells depending on the fetal age, Suppl. Fig. S2E) was significantly diminished following ibuprofen exposure $(P=0.0038$ and $P<0.001$, for $7 \mathrm{DW}$ and 8-12 DW, respectively), with a large reduction when exposed to $10 \mu \mathrm{M}$ (Fig. 3B). In terms of total M2A-positive cell number, the germ cell population expanded exponentially from 7 to $12 \mathrm{DW}$, increasing from $4 \times 10^{4}$ to over $3 \times$ $10^{5}$ M2A-high positive cells per ovary in control conditions (Fig. 3C). Following ibuprofen treatment, I and $100 \mu \mathrm{M}$ doses both induced on average a $30 \%$ depletion of the germ cell count, whereas $10 \mu \mathrm{M}$ ibuprofen led to a significant (50-75\%) loss of germ cells, depending on the fetal age (Fig. 3C). Thus, unequivocally, ibuprofen exposure resulted in a decrease in the number of M2A-positive germ cells.

\section{Ibuprofen-induced adverse effects after 2 days of exposure were not reversible by a 5-day withdrawal period}

We next investigated the effects of shorter exposures of $10 \mu \mathrm{M}$ ibuprofen, a dose shown to be deleterious for the organ (Fig. 4). Whereas overall cell death remained low in all control explants 


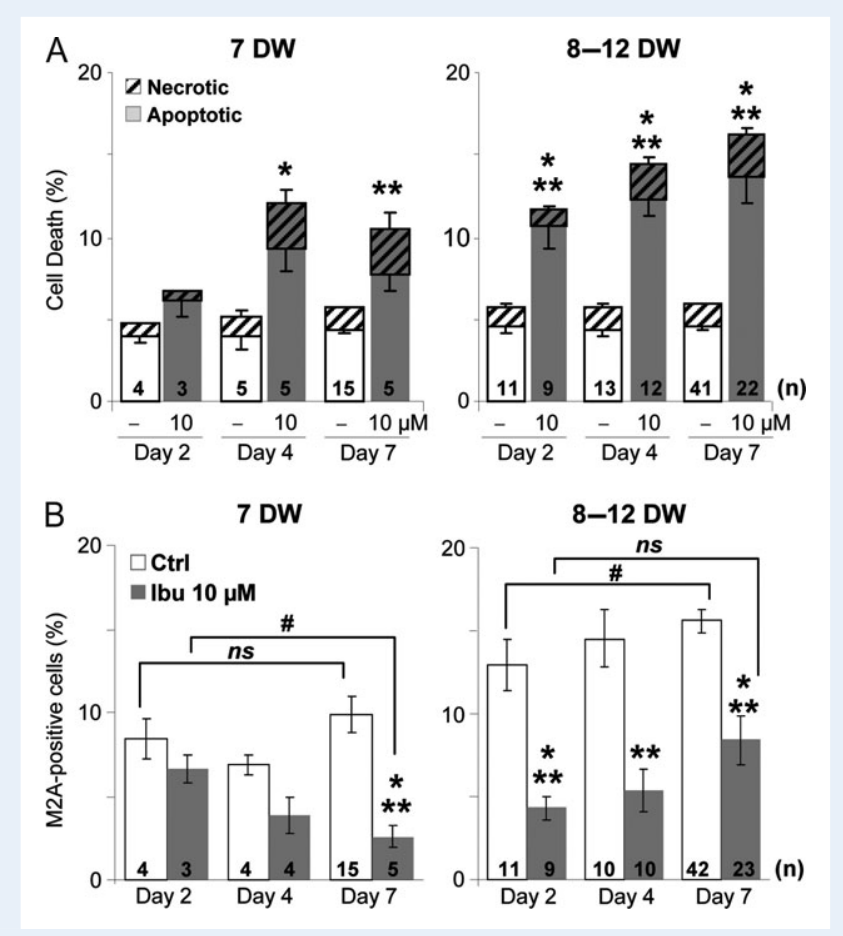

Figure 4 Ibuprofen cytotoxic effect on ovarian fetal germ cells is detectable as early as 2 days after treatment. (A) Analysis of cell death by flow cytometry after 2, 4, or 7 days of exposure to either vehicle (-, white bars) or $10 \mu \mathrm{M}$ ibuprofen (gray bars). Plain bars represent apoptosis and hatched bars necrosis. (B) Quantification of M2Aexpressing germ cells in fetal ovaries treated as in A. The ** and *** above the bars of the histogram indicate the Mann-Whitney post-hoc test compared to control has a P-value $<0.01$ and $<0.00$ I, respectively. The \# indicates the Mann-Whitney post-hoc test compared to the same condition after 2 days of culture has a P-value $<0.05$. ns means non-significant. $(n)$ indicates the number of individual per condition.

regardless of the fetal age, the percentage of apoptotic cells progressively increased as early as 2 days after the beginning of the treatment (Fig. 4A). Ibuprofen significantly induced cell death from 4 days of exposure in the $7 \mathrm{DW}$ age group $(P=0.028$ and 0.0079 after 4 and 7 days, respectively), and as early as 2 days of exposure in the $8-12 \mathrm{DW}$ group $\left(P=0.00058 ; 3.84 \times 10^{-7}\right.$, and $3.03 \times 10^{-8}$ after 2,4 and 7 days, respectively) (Fig. 4A). In addition, in young $7 \mathrm{DW}$ explants, M2A-positive germ cell depletion was progressively enhanced and became significant after 7 days of ibuprofen exposure (Fig. 4B). Of concern, M2A-germ cell depletion in 8-12 DW explants reached its maximum of $-66.7 \%$ as rapidly as 2 days following ibuprofen treatment.

We next assessed the recovery capacity of this organ following ibuprofen withdrawal. Explants (10-12 DW) were exposed to $10 \mu \mathrm{M}$ ibuprofen for 2 days, and subsequently cultured in control media without ibuprofen for a further 5 days (Fig. 5A). No significant difference in the overall cell death percentage at 7 days of culture was seen whether or not a 5-day recovery period had been allowed after the initial 2 days of ibuprofen-treatment $(15.98 \pm 2.38$ versus $11.86 \pm 1.31$, Means \pm SEM, $P=0.47)$. Likewise, the apoptosis rate induced by 2 days of
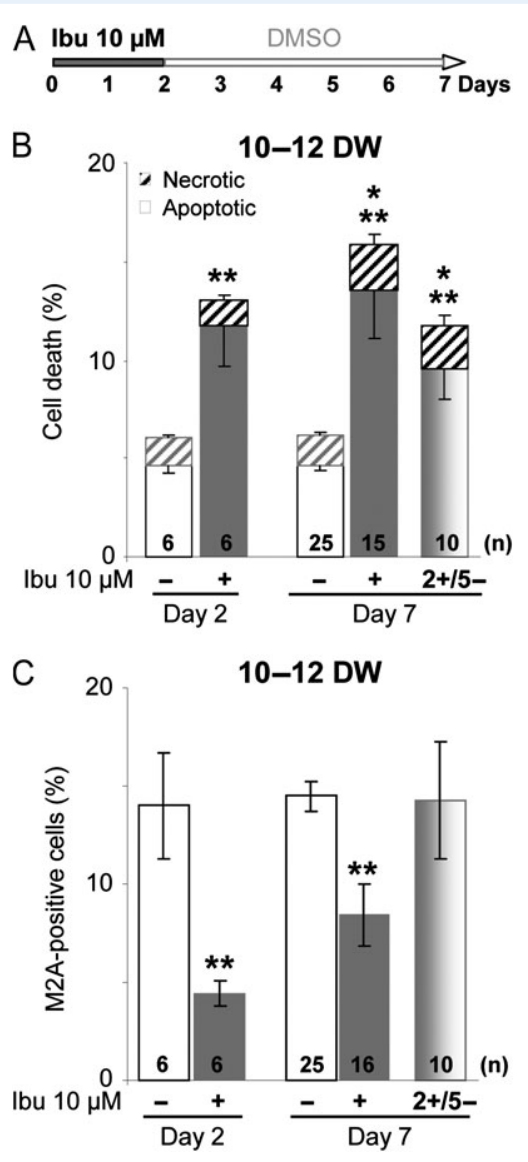

Figure 5 Ibuprofen withdrawal after a short-term exposure does not efficiently rescue the cytotoxic effect of the drug. (A) A drug withdrawal protocol was set up as follow: 10-12 DW explants were exposed to ibuprofen $10 \mu \mathrm{M}$ for 2 days, then kept in culture with fresh control media deprived of ibuprofen for another 5 days. Flow cytometric analysis of cell death $(\mathbf{B})$ and M2A-positive cells $(\mathbf{C})$ for this withdrawal treatment $(2+/ 5-$; gray to white gradation bar) was compared to either a 2 day or a 7 day exposure, to either vehicle (-, white bars) or ibuprofen at $10 \mu \mathrm{M}$ (+, gray bars). ${ }^{* *}$ and ${ }^{* * *}$ above the bars indicates the Mann-Whitney post-hoc test compared to control has a P-value $<0.0$ I and $<0.00$ I, respectively. ( $n$ ) indicates the number of individual per condition.

ibuprofen exposure was not significantly reduced after a 5-day recovery (Fig. $5 \mathrm{~B}$; $13.50 \pm 2.27$ versus $9.58 \pm 1.52$, Means $\pm \mathrm{SEM}, P=$ $0.43)$. However, the percentage of $M 2 A$-positive germ cells increased along with the 5 days recovery compared to the 2-day ibuprofen treatment alone, returning to its control level (Fig. 5C). These data most probably indicate that the cytotoxic effect induced by a 2 day ibuprofen exposure was not fully rescued by a 5 day-long withdrawal of the drug, despite an improvement of the germ cell percentage.

\section{Discussion}

Ibuprofen is one of the most widely used over-the-counter analgesicantipyretic-anti-inflammatory medication. It has even been presented as 'the mildest NSAID with the fewest side effects which has been in 
clinical use for a long time' (Rainsford, 2009; Servey and Chang, 2014). During the third trimester of pregnancy, all NSAIDs are currently contra-indicated due to risks of severe cardiopulmonary toxicity and renal dysfunction in the fetus (Black and Hill, 2003; Servey and Chang, 2014). Several studies have reported the consumption of ibuprofen by pregnant women, with percentages of exposed women reaching up to 30\% (Kristensen et al., 20 I6; Van Marter et al., 2013). Consistent with current recommendations, the majority of women using ibuprofen do so during the first trimester and frequency decreases thereafter (Glover et al., 2003; Nezvalova-Henriksen et al., 20 I3; Palmsten et al., 20 16; Stephansson et al., 20 I I; Wen et al., 2008; Werler et al., 2005). We here report that ibuprofen, a non-selective inhibitor of COX, induces a decreased cell proliferation and an increased cell death in first trimester human fetal ovaries mainly due to effects on fetal germ cells. This raises concern about ibuprofen consumption by pregnant women during the fetal ovarian organogenesis period and a subsequent risk for the establishment of the follicular reserve.

\section{Ibuprofen crosses the placental barrier during the first trimester of pregnancy}

Paracetamol and acetyl salicylic acid can cross the human placental barrier (Jacobson et al., 1991; Levy et al., 1975; Naga Rani et al., 1989; Weigand et al., 1984). In rats and rabbits, ibuprofen and its metabolites can also readily enter the fetal circulation (Adams et al., 1969). In human, ibuprofen was found in the meconium of newborn infants (Alano et al., 200I). However, to the best of our knowledge, there has not been any direct measurement of the ability of ibuprofen to cross the placental barrier and its subsequent plasma levels in human fetuses.

Here, we took advantage of the use of ibuprofen for preventive analgesia by women undergoing abortion to investigate the circulating levels of ibuprofen in umbilical cord blood. We were able to reveal that when the woman ingested ibuprofen before abortion, it was detectable in the umbilical cord blood in concentrations ranging from 0.4 to $14 \mu \mathrm{M}$. Notably, the range of circulating ibuprofen depended more on the delay between ingestion and blood collection than on the ingested dose ( 400 versus $800 \mathrm{mg}$ ), the highest levels being found when this delay was between 3 and $6 \mathrm{~h}$. In adults, the maximal therapeutic plasma concentration for ibuprofen has been defined in the $100 \mu \mathrm{M}$ range for oral doses between 400 and $800 \mathrm{mg}$ (Ceppi Monti et al., 1992; Kallstrom et al., 1988; Karttunen et al., 1990; Regazzi et al., 1986) and about $200 \mu \mathrm{M}$ in children (Scott et al., 1999). Our results thus show for the first time that placental transfer of ibuprofen occurs as early as in the first trimester, and exposes the fetus to concentrations between I and $10 \mu \mathrm{M}$.

\section{Ibuprofen impacts the growth of the human fetal ovary}

Ovarian development is characterized by cell proliferation of both somatic and germ cell lineages (Fulton et al., 2005). During the first trimester, the oogonia actively proliferate and from the end of the first trimester, a subset of germ cells commit to meiosis (Jorgensen and Rajpert-De Meyts, 20I4). In agreement with previous histological studies (Mamsen et al., 20II), we report that in uncultured ovaries, the total number of cells at least quadruples from 7 to $12 \mathrm{DW}\left(2.6 \times 10^{5}\right.$ cells at $7 \mathrm{DW}$ versus $1.3 \times 10^{6}$ cells at $\left.12 \mathrm{DW}\right)$. Importantly, cell growth kept occurring over the course of 7 days in culture $\left(4.5 \times 10^{5}\right.$ cells, i.e. $+190,000$ cells for $7 \mathrm{DW}$ and $2 \times 10^{6}$ cells, i.e. $+700,000$ cells for 12 DW cultured explants). The active proliferation of the germ cells was also evidenced ex vivo, where the M2A-positive cell population proliferates five times from 7 to $12 \mathrm{DW}$ after 7 days of culture (from $4.7 \times 10^{4}$ to over $3 \times 10^{5}$ germ cells per cultured ovary) and increases 1.5 times after 7 days of culture (from $2.2 \times 10^{5}$ in uncultivated ovaries to $3 \times 10^{5}$ germ cells after 7 days of culture for 12 DW ovaries). Accordingly, K167 immunostaining confirmed both somatic and germ cell proliferation ex vivo. Ovarian development during the first trimester has also been characterized by a low rate of apoptosis where apoptotic cells were mostly identified as oogonia (Fulton et al., 2005). Consistently, we found a similarly weak density of cleaved caspase-3-positive cells after 7 days of control culture and our flow cytometry data displayed equally low cell death rate in both fresh organ and ex vivo culture (close to 6\%). Overall, these data suggest that the organotypic culture by itself did not impact either the high proliferation or the low apoptotic rates, therefore allowing the development of the ovary. By contrast, following exposure to ibuprofen, we have shown a reduction of the overall number of ovarian cells, effect coupled to a dramatic decline of cell proliferation and a significant enhancement of apoptosis, but not necrosis. This suggests that ibuprofen compromised both proliferation and viability, ultimately resulting in a loss of ovarian cells. At this stage, we cannot speculate if both events are linked or simply concomitant.

It has been over two decades since several studies have reported a role for ibuprofen and other NSAIDs in cancer prevention (Matos and Jordan, 20I5). In cancer cell lines, ibuprofen is also known to alter cell proliferation and viability, the resulting cell growth slowdown being often associated with cell cycle arrest. In many cases, such as colon carcinoma (Andrews et al., 2008; Janssen et al., 2006, 2008), prostate cancer (Andrews et al., 2002, 2008; Minnery and Getzenberg, 2005), oral cavity cancer cell lines (Kim et al., 2004; Thurnher et al., 200I) and ovarian cancer cell lines (Andrews et al., 2008; Duncan et al., 2012; Lima et al., 20I5), ibuprofen also induces apoptosis. Similar to its mechanism of action in cancer cells, we observed that ibuprofen alters both proliferation and cell death in human fetal ovary. At a molecular level, studies in several cell lines have suggested a TP53dependent mechanism of ibuprofen toxicity that also involves an increase in the expression of CDKNIA (also known as p2I) (Bonelli et al., 20 I I; Ikegaki et al., 20 I4; Janssen et al., 2008; Tsai et al., 2004). We found similar increases in TP53 and CDKNIA expression in the human fetal ovary after exposure to ibuprofen, suggesting that ibuprofen toxicity in the human fetal ovary may use a similar signaling pathway, and may act on molecular targets placed at the crossroad of proliferation and cell death. Further experiments will be required to investigate the fine molecular mechanism of action of ibuprofen on the human fetal ovary.

Interestingly, in four ovarian cancer cell lines (SKOV-3, CAOV-3, 36M2 and SW626) (Duncan et al., 20I2), only the high concentration of $200 \mu \mathrm{M}$ ibuprofen was shown to induce apoptosis, whereas doses ranging from 20 to $100 \mu \mathrm{M}$ had no cytotoxic effect on the same cells. This suggests that ibuprofen may use different signaling pathways depending on the concentration of exposure, as well as the tumoral/ physiological state of the cellular target. In our ex vivo model, the overall impact of ibuprofen was most pronounced when used at $10 \mu \mathrm{M}$ and notably more variable at $100 \mu \mathrm{M}$. Non-monotonic dose-response 
curves have been described in the testis where several endocrine disruptor compounds exhibited these curves (Gaudriault et al., 2017). In the ovary, only two studies have investigated several concentrations (of either Bisphenol A or dexamethasone) and found linear doseresponse curves (Brieno-Enriquez et al., 20II; Poulain et al., 20I2). Non-linear dose-response effects are often associated with differences in the mechanism of action, such as induction of the detoxification pathway, alteration of signaling pathways or saturation of metabolic pathways (Vandenberg et al., 2012). Therefore, ibuprofen mechanism of action requires further investigations. Importantly, however, it is noteworthy that during the first trimester the developing fetuses are more likely to be exposed to the active concentrations of $10 \mu \mathrm{M}$ and below.

\section{Ibuprofen targets the germ cell lineage}

We have shown that $10 \mu \mathrm{M}$ ibuprofen efficiently inhibited PGE2 production by human fetal ovaries, as has been shown previously in human fetal testis culture (Ben Maamar et al., 2017; Mazaud-Guittot et al., 20I3), and in vivo in the rat (Dean et al., 20I6). In the human fetal ovary, COXI is expressed by somatic cells, while COX2 and PTGES are confined to germ cells during the first and second trimesters (Bayne et al., 2009). Furthermore, previous studies have reported that exposure of human fetal ovaries to PGE2 (8h exposure at $0.1 \mu \mathrm{M}$ ) increased the mRNA levels of $M L C I$ and INHA, two markers of mature germ cells (Bayne et al., 2009), suggesting a favorable impact of PGE2 on germ cell development. In the rat, in utero exposure to either indomethacin $(0.8 \mathrm{mg} / \mathrm{kg} \mathrm{d})$ or paracetamol $(350 \mathrm{mg} / \mathrm{kg}$.d) between 13.5 and 21.5 days post-conception (dpc) altered the expression of some germ cell markers (Dean et al., 20I6), while ex vivo exposure of 12.5 $\mathrm{dpc}$ mouse ovaries to $100 \mu \mathrm{M}$ paracetamol for 3 days did not alter the expression of several typical germ cell markers (Holm et al., 20I6). In the human fetal ovary, our ex vivo data reveal that ibuprofen massively impacts the viability of the germ cell lineage. It is thus reasonable to propose that the exacerbated effects of ibuprofen in 8-12 DW ovaries (compared to $7 \mathrm{DW}$ organs) may be related to the increasing proportion in germ cells and their production of PGE2 at this stage.

Noteworthy, we observed that withdrawal of ibuprofen for 5 days after continuous exposure for 2 days allowed for a rescue of M2Apositive germ cell percentage, but with a persistent high apoptosis rate. We hypothesize that germ cells surviving the 2 days of ibuprofen exposure may proliferate rapidly after termination of drug administration, resulting in complete ovarian potential 5 days after exposure ended. Therefore, at the cellular level, the negative effect of ibuprofen on the germ cell lineage viability might be limited. This does not however exclude potential damage at the molecular level, such as DNA damage as suggested by inherited impact of paracetamol and indomethacin, another NSAID, in the germ cells of the rat (Dean et al., 2016).

While overexpression of COX2 and increased prostaglandin biosynthesis has been observed during carcinogenesis (Harris, 2007), NSAIDs anti-tumoral effect has been to a large part attributed to their inhibition of COX enzymes (Matos and Jordan, 20I5). Because COX2 expression is restricted to germ cells during fetal development (Bayne et al., 2009), it could be hypothesized that ibuprofen would preferentially target cells expressing high COX2 levels, such as tumor and fetal germ cells. However, if the canonical mechanism of action of ibuprofen and other NSAIDs rely on the inhibition of prostaglandin synthesis, ibuprofen can also display cytotoxic effects independently of COX2 expression or activity (Andrews et al., 2008; Janssen et al., 2008). The specific mechanism(s) of action of ibuprofen on ovotoxicity and germ cell viability thus requires further detailed investigations.

Overall, our data reveal that a 2-7 days exposure to the nonselective COX inhibitor ibuprofen, at concentrations relevant to in utero conditions impacts the germ cell stockpile in human fetal ovaries in the first trimester of pregnancy. The incomplete capacity for rescue of the fetal ovary to ibuprofen-induced damages suggests that prolonged exposure to ibuprofen during fetal life may lead to long-term effects on female reproductive function. This raises concern about ibuprofen consumption by pregnant women during the fetal ovarian organogenesis period, and the subsequent risk for the establishment of the follicular reserve.

\section{Supplementary data}

Supplementary data are available at Human Reproduction online.

\section{Acknowledgements}

We thank all the staff of the Department of Obstetrics and Gynecology and the Department of Pediatric Surgery of the Rennes Sud Hospital (Rennes, France) and the participating women, without whom this study would not have been possible. The authors are grateful for Isabelle Coiffec for assistance on organ collection and the H2P2 histology facility of Rennes I University. We also thank the Edinburgh CRF Mass Spectrometry Core.

\section{Authors' roles}

S.L.P. and S.M.G. designed, performed and analyzed experiments (culture, histology, cell counts and cytometry for S.L.P.; organ collection, culture, histology and QtPCR for S.M.G.). R.T.M. and N.H. designed and conducted the ibuprofen measurements. M.B.M. performed experiments (organ and blood collection, culture). L.L. performed experiments (culture, cytometry). E.B. performed the statistical analyses and contributed to the writing of the corresponding section. V.L. supervised the collection of the first trimester human fetal ovarian samples. S.M.G. conceptualized the project, S.L.P. and S.M.G. prepared the visualization of the data and wrote the original draft, N.D.R., D.M.K., F.C. and B.J. contributed to critical discussions, reviewed and edited the manuscript, and all authors approved the final manuscript.

\section{Funding}

This study was funded by Inserm, University of Rennes I, EHESPSchool of Public Health, by grants from the Agence Nationale de Sécurité du Médicament et des Produits de Santé (ANSM; HAP-20I4073), Agence Nationale de la Recherche (ANR-I5-CE34-000I-0I) and the Danish Council for independent Research (Medical Sciences), and the Wellcome Trust (Grant no: 098522). 


\section{Conflict of interest}

The authors declare they have no competing financial interest and funders had no role in the study design, data collection and analysis, decision to publish or preparation of the manuscript.

\section{References}

Adams SS, Bough RG, Cliffe EE, Lessel B, Mills RF. Absorption, distribution and toxicity of ibuprofen. Toxicol Appl Pharmacol 1969;15:3 I0-330.

Alano MA, Ngougmna E, Ostrea EM Jr, Konduri GG. Analysis of nonsteroidal antiinflammatory drugs in meconium and its relation to persistent pulmonary hypertension of the newborn. Pediatrics 200 I; 1 07:5 I9-523.

Andrews J, Djakiew D, Krygier S, Andrews P. Superior effectiveness of ibuprofen compared with other NSAIDs for reducing the survival of human prostate cancer cells. Cancer Chemother Pharmacol 2002;50:277-284.

Andrews P, Zhao X, Allen J, Li F, Chang M. A comparison of the effectiveness of selected non-steroidal anti-inflammatory drugs and their derivatives against cancer cells in vitro. Cancer Chemother Pharmacol 2008;6 I: 203-2।4.

Bayne RA, Eddie SL, Collins CS, Childs AJ, Jabbour HN, Anderson RA. Prostaglandin E2 as a regulator of germ cells during ovarian development. J Clin Endocrinol Metab 2009;94:4053-4060.

Ben Maamar M, Lesne L, Hennig K, Desdoits-Lethimonier C, Kilcoyne KR, Coiffec I, Rolland AD, Chevrier C, Kristensen DM, Lavoue $V$ et al. Ibuprofen results in alterations of human fetal testis development. Sci Rep 2017;7:44I84.

Black RA, Hill DA. Over-the-counter medications in pregnancy. Am Fam Physician 2003;67:2517-2524.

Bonelli P, Tuccillo FM, Calemma R, Pezzetti F, Borrelli A, Martinelli R, De Rosa A, Esposito D, Palaia R, Castello G. Changes in the gene expression profile of gastric cancer cells in response to ibuprofen: a gene pathway analysis. Pharmacogenomics J 20 I I; I I:4 I2-428.

Brieno-Enriquez MA, Robles P, Camats-Tarruella N, Garcia-Cruz R, Roig I, Cabero L, Martinez F, Caldes MG. Human meiotic progression and recombination are affected by Bisphenol $A$ exposure during in vitro human oocyte development. Hum Reprod 20 I ; 26:2807-28I8.

Ceppi Monti N, Gazzaniga A, Gianesello V, Stroppolo F, Lodola E. Activity and pharmacokinetics of a new oral dosage form of soluble ibuprofen. Arzneimittelforschung 1992;42:556-559.

Chang HY, Shih MH, Huang HC, Tsai SR, Juan HF, Lee SC. Middle infrared radiation induces $\mathrm{G} 2 / \mathrm{M}$ cell cycle arrest in A549 lung cancer cells. PLoS One 2013;8:e54117.

Childs AJ, Kinnell HL, He J, Anderson RA. LIN28 is selectively expressed by primordial and pre-meiotic germ cells in the human fetal ovary. Stem Cells Dev 2012;21:2343-2349.

Dean A, van den Driesche S, Wang Y, McKinnell C, Macpherson S, Eddie SL, Kinnell H, Hurtado-Gonzalez P, Chambers TJ, Stevenson K et al. Analgesic exposure in pregnant rats affects fetal germ cell development with inter-generational reproductive consequences. Sci Rep 2016;6: 19789.

Duffy DM. Novel contraceptive targets to inhibit ovulation: the prostaglandin E2 pathway. Hum Reprod Update 2015;2 I:652-670.

Duncan K, Uwimpuhwe H, Czibere A, Sarkar D, Libermann TA, Fisher PB, Zerbini LF. NSAIDs induce apoptosis in nonproliferating ovarian cancer cells and inhibit tumor growth in vivo. IUBMB Life 20 12;64:636-643.

Edson MA, Nagaraja AK, Matzuk MM. The mammalian ovary from genesis to revelation. Endocr Rev 2009;30:624-7/2.

Fulton N, Martins da Silva SJ, Bayne RA, Anderson RA. Germ cell proliferation and apoptosis in the developing human ovary. J Clin Endocrinol Metab 2005;90:4664-4670.
Gaudriault P, Mazaud-Guittot S, Lavoue V, Coiffec I, Lesne L, DejucqRainsford N, Scholze M, Kortenkamp A, Jegou B. Endocrine disruption in human fetal testis explants by individual and combined exposures to selected pharmaceuticals, pesticides, and environmental pollutants. Environ Health Perspect 2017; 1 25:087004.

Glover DD, Amonkar M, Rybeck BF, Tracy TS. Prescription, over-thecounter, and herbal medicine use in a rural, obstetric population. Am J Obstet Gynecol 2003; I 88: 1039-1045.

Harris RE. Cyclooxygenase-2 (cox-2) and the inflammogenesis of cancer. Subcell Biochem 2007;42:93-126.

Holm JB, Mazaud-Guittot S, Danneskiold-Samsoe NB, Chalmey C, Jensen B, Norregard MM, Hansen CH, Styrishave B, Svingen T, Vinggaard AM et al. Intrauterine exposure to paracetamol and aniline impairs female reproductive development by reducing follicle reserves and fertility. Toxicol Sci 2016;150: 178-189.

Ikegaki N, Hicks SL, Regan PL, Jacobs J, Jumbo AS, Leonhardt P, Rappaport EF, Tang XXS. -ibuprofen destabilizes MYC/MYCN and $A K T$, increases $p 53$ expression, and induces unfolded protein response and favorable phenotype in neuroblastoma cell lines. Int J Oncol 20 I4;44: $35-43$.

Jacobson RL, Brewer A, Eis A, Siddiqi TA, Myatt L. Transfer of aspirin across the perfused human placental cotyledon. Am J Obstet Gynecol 1991; 165:939-944.

Janssen A, Maier TJ, Schiffmann S, Coste O, Seegel M, Geisslinger G, Grosch S. Evidence of COX-2 independent induction of apoptosis and cell cycle block in human colon carcinoma cells after S- or R-ibuprofen treatment. Eur J Pharmacol 2006;540:24-33.

Janssen A, Schiffmann S, Birod K, Maier TJ, Wobst I, Geisslinger G, Grosch S. p53 is important for the anti-proliferative effect of ibuprofen in colon carcinoma cells. Biochem Biophys Res Commun 2008;365:698-703.

Jin ZW, Kim YG, Yu HC, Murakami G, Fujimiya M, Cho BH. A comparison between D2-40 and c-KIT immunohistochemistry for the human fetal testis and ovary at the second trimester of gestation. Okajimas Folia Anat Jpn 2010;87: I-4.

Johansson HK, Jacobsen PR, Hass U, Svingen T, Vinggaard AM, Isling LK, Axelstad M, Christiansen S, Boberg J. Perinatal exposure to mixtures of endocrine disrupting chemicals reduces female rat follicle reserves and accelerates reproductive aging. Reprod Toxicol 2016;6 I: 186-194.

Jorgensen A, Rajpert-De Meyts E. Regulation of meiotic entry and gonadal sex differentiation in the human: normal and disrupted signaling. Biomol Concepts 20I4;5:33I-34I.

Kallstrom E, Heikinheimo M, Quiding H. Bioavailability of three commercial preparations of ibuprofen 600 mg. J Int Med Res 1988; 16:44-49.

Karttunen P, Saano V, Paronen P, Peura P, Vidgren M. Pharmacokinetics of ibuprofen in man: a single-dose comparison of two over-the-counter, 200 mg preparations. Int J Clin Pharmacol Ther Toxicol 1990;28:25I-255.

Kerr JB, Myers M, Anderson RA. The dynamics of the primordial follicle reserve. Reproduction 20 I3; I 46:R205-R2 I5.

Kim KS, Yoon JH, Kim JK, Baek SJ, Eling TE, Lee WJ, Ryu JH, Lee JG, Lee $\mathrm{JH}$, Yoo JB. Cyclooxygenase inhibitors induce apoptosis in oral cavity cancer cells by increased expression of nonsteroidal anti-inflammatory drug-activated gene. Biochem Biophys Res Commun 2004;325:12981303.

Kripp M, Merx K, Wirtz RM, Gaiser T, Eidt S, Schwaab J, Post S, Wenz F, Hochhaus A, Hofheinz RD et al. Prognostic impact of mRNA expression levels of HERI-4 (ERBBI-4) in patients with locally advanced rectal cancer. Gastroenterol Res Pract 2016;20 16:348I 578.

Kristensen DM, Mazaud-Guittot S, Gaudriault P, Lesne L, Serrano T, Main $K M$, Jegou $B$. Analgesic use - prevalence, biomonitoring and endocrine and reproductive effects. Nat Rev Endocrinol 201 6; I 2:38I-393.

Le Bouffant R, Guerquin MJ, Duquenne C, Frydman N, Coffigny $H$, Rouiller-Fabre V, Frydman R, Habert R, Livera G. Meiosis initiation in 
the human ovary requires intrinsic retinoic acid synthesis. Hum Reprod 2010;25:2579-2590.

Levy G, Procknal JA, Garrettson LK. Distribution of salicylate between neonatal and maternal serum at diffusion equilibrium. Clin Pharmacol Ther 1975; 18:210-214.

Lima RA, Candido EB, de Melo FP, Piedade JB, Vidigal PV, Silva LM, da Silva Filho AL. Gene expression profile of $A B C$ transporters and cytotoxic effect of ibuprofen and acetaminophen in an epithelial ovarian cancer cell line in vitro. Rev Bras Ginecol Obstet 2015;37:283-290.

Mamsen LS, Lutterodt MC, Andersen EW, Byskov AG, Andersen CY. Germ cell numbers in human embryonic and fetal gonads during the first two trimesters of pregnancy: analysis of six published studies. Hum Reprod 201।;26:2।40-2।45.

Matos P, Jordan P. Beyond COX-inhibition: 'side-effects' of ibuprofen on neoplastic development and progression. Curr Pharm Des 2015;21:2978-2982.

Mazaud-Guittot S, Nicolas Nicolaz C, Desdoits-Lethimonier C, Coiffec I, Ben Maamar M, Balaguer P, Kristensen DM, Chevrier C, Lavoue V, Poulain $\mathrm{P}$ et al. Paracetamol, aspirin, and indomethacin induce endocrine disturbances in the human fetal testis capable of interfering with testicular descent. J Clin Endocrinol Metab 20 I3;98:E I 757-EI 767.

McGee EA, Hsueh AJ. Initial and cyclic recruitment of ovarian follicles. Endocr Rev 2000;21:200-214.

Minnery $\mathrm{CH}$, Getzenberg RH. Benign prostatic hyperplasia cell line viability and modulation of jm-27 by doxazosin and Ibuprofen. J Urol 2005; 174: 375-379.

Naga Rani MA, Joseph T, Narayanan R. Placental transfer of paracetamol. J Indian Med Assoc 1989;87: I 82-183.

Nelson SM, Telfer EE, Anderson RA. The ageing ovary and uterus: new biological insights. Hum Reprod Update 2013;19:67-83.

Nezvalova-Henriksen K, Spigset O, Nordeng H. Effects of ibuprofen, diclofenac, naproxen, and piroxicam on the course of pregnancy and pregnancy outcome: a prospective cohort study. Bjog 20 I3; I 20:948-959.

Palmsten K, Hernandez-Diaz S, Chambers CD, Mogun H, Lai S, Gilmer TP, Huybrechts KF. The most commonly dispensed prescription medications among pregnant women enrolled in the U.S. Medicaid Program. Obstet Gynecol 20 I 6; I 26:465-473.

Poulain M, Frydman N, Duquenne C, N'Tumba-Byn T, Benachi A, Habert R, Rouiller-Fabre V, Livera G. Dexamethasone induces germ cell apoptosis in the human fetal ovary. J Clin Endocrinol Metab 2012;97:EI 890-El 897.

Rainsford KD. Ibuprofen: pharmacology, efficacy and safety. Inflammopharmacology 2009; 1 7:275-342.

Regazzi BM, Rondanelli R, Ciaroelli L, Bartoli AL, Rampini A. Evaluation of the absorption from three ibuprofen formulations. Int J Clin Pharmacol Res 1986;6:469-473.

Scott CS, Retsch-Bogart GZ, Kustra RP, Graham KM, Glasscock BJ, Smith PC. The pharmacokinetics of ibuprofen suspension, chewable tablets, and tablets in children with cystic fibrosis. J Pediatr 1999; 134:58-63.

Selvarajah J, Elia A, Carroll VA, Moumen A. DNA damage-induced S and G2/M cell cycle arrest requires mTORC2-dependent regulation of Chkl. Oncotarget 20I 5;6:427-440.
Servey J, Chang J. Over-the-counter medications in pregnancy. Am Fam Physician 2014;90:548-555.

Stephansson O, Granath F, Svensson T, Haglund B, Ekbom A, Kieler H. Drug use during pregnancy in Sweden - assessed by the Prescribed Drug Register and the Medical Birth Register. Clin Epidemiol 201 1;3:4350.

Sugimoto $\mathrm{Y}$, Inazumi T, Tsuchiya S. Roles of prostaglandin receptors in female reproduction. J Biochem 20I5; I57:73-80.

Svingen T, Jorgensen A, Rajpert-De Meyts E. Validation of endogenous normalizing genes for expression analyses in adult human testis and germ cell neoplasms. Mol Hum Reprod 2014;20:709-7I8.

Thorpe PG, Gilboa SM, Hernandez-Diaz S, Lind J, Cragan JD, Briggs G, Kweder S, Friedman JM, Mitchell AA, Honein MA. Medications in the first trimester of pregnancy: most common exposures and critical gaps in understanding fetal risk. Pharmacoepidemiol Drug Saf 2013;22:10131018.

Thurnher D, Bakroeva M, Schutz G, Pelzmann M, Formanek M, Knerer B, Kornfehl J. Non-steroidal anti-inflammatory drugs induce apoptosis in head and neck cancer cell lines. Acta Otolaryngol 200 I; I 2 I:957-962.

Tsai WC, Tang FT, Hsu CC, Hsu YH, Pang JH, Shiue CC. Ibuprofen inhibition of tendon cell proliferation and upregulation of the cyclin kinase inhibitor p2 I CIPI. J Orthop Res 2004;22:586-59I.

Van Marter LJ, Hernandez-Diaz S, Werler MM, Louik C, Mitchell AA. Nonsteroidal antiinflammatory drugs in late pregnancy and persistent pulmonary hypertension of the newborn. Pediatrics 20 |3; | 3 1:79-87.

VandenbergLNColbornTHayesTBHeindelJjJacobsDRJrLeeDHShiodaTSotoAMvom SaalFSWelshonsWVet al20I2Hormones and endocrinedisrupting chemicals: low-dose effects and nonmonotonic dose responsesEndocr Rev33378455

Weigand UW, Chou RC, Maulik D, Levy G. Assessment of biotransformation during transfer of propoxyphene and acetaminophen across the isolated perfused human placenta. Pediatr Pharmacol (New York) 1984;4: 145-153.

Wen SW, Yang T, Krewski D, Yang Q, Nimrod C, Garner P, Fraser W, Olatunbosun $O$, Walker MC. Patterns of pregnancy exposure to prescription FDA C, D and $X$ drugs in a Canadian population. J Perinatol 2008;28:324-329.

Wang J, Huang S, Xing L, Shen H, Yan X, Wang J, Zhang X. Role of hMLHI in sterigmatocystin-induced $G(2)$ phase arrest in human esophageal epithelial Het-IA cells in vitro. Toxicol Lett 20I3;2 17:226-234.

Werler MM, Mitchell AA, Hernandez-Diaz S, Honein MA. Use of overthe-counter medications during pregnancy. Am J Obstet Gynecol 2005; 193:77।-777.

Yang Y, Nguyen TT, Jeong MH, Crisan F, Yu YH, Ha HH, Choi KH, Jeong HG, Jeong TC, Lee KY et al. Inhibitory activity of (+)-usnic acid against non-small cell lung cancer cell motility. PLoS One 20 I 6; I I :e0 I 46575.

Zerbini LF, Tamura RE, Correa RG, Czibere A, Cordeiro J, Bhasin M, Simabuco FM, Wang Y, Gu X, Li L et al. Combinatorial effect of nonsteroidal anti-inflammatory drugs and NF-kappaB inhibitors in ovarian cancer therapy. PLoS One 20 I ।;6:e24285. 